\title{
Political economy of pension reforms: selected general issues and the Polish pension reform case
}

Marek Góra

\author{
Correspondence: marek.gora@sgh. \\ waw.pl \\ Warsaw School of Economics, \\ Warsaw, Poland and IZA
}

\begin{abstract}
The institutional structures of the various types of European welfare state were established around extra revenues called the "demographic dividend" that used to be easily available throughout the decades of the 20st century. They, however, ceased to be available at the end of that century. The challenge societies face today is how to manage the institutions having relatively less resources available for their financing.

In this paper I analyse selected political economy issues related to pension reforms, such as the worker-retiree conflict of interest, distribution by age of the costs of the loss of demographic dividend, and key goals behind pension reforms. The focus of this paper is on pension reforms in Poland, which actually was an implementation of a thoroughly new pension system. Its design is analysed and discussed from a political economy viewpoint. Furthermore, analysis of the Polish pension system is presented in a broader European context.

Jel codes: $\mathrm{H} 55 ; \mathrm{I} 31 ; \mathrm{J} 11 ; \mathrm{J} 18$.
\end{abstract}

\section{Introduction}

Throughout Europe, pension systems as well as public finance in general are strongly exposed to the challenges of the $21^{\text {st }}$ century. This applies to the more affluent EU15 as well as to the less affluent new EU member states (Alesina \& Glaeser 2004). In both cases the reason is the same: population changes lie at the root of the problem, as the institutional structures of the various types of European welfare state or European Social Model were established around extra revenues called the "demographic dividend" that used to be easily available throughout the decades of the 20st century. They, however, ceased to be available at the end of that century when most, if not all, European societies reached stage four of their demographic transition (Atkinson 1995).

Pension systems are deeply rooted in the public perception of societies. This applies not only to developed countries but also to those various countries that were historically linked to the European institutional tradition. Pension systems belong to core institutional systems that are expected to be very stable and reliable. That perception has been developed over many decades when consecutive generations of citizens participated and benefited from that participation. Over time, the link between welfare and work effort has weakened. The public internalised that situation and began to perceive welfare as being granted, solely on the premise they were the citizens of affluent and well organised countries. 
European countries still try to manage these pension institutions as if the dividend was still available. Governments focus mostly on the inevitable fiscal cuts from such a situation, even though it is deep social reforms that are needed. Europe is less affluent than European citizens tend to assume. With smaller resources available, they need to rethink the way these may be distributed within societies. Pension systems are probably most directly exposed to the problems stemming from the loss of the "demographic dividend". At the same time, in terms of GDP, pension systems in Europe are large or very large. Consequently, they influence the economic and social situations the most. Various pension reforms are on the top of policy agendas throughout Europe. These reforms are very often contested by societies. Managing the disillusion is the challenge. It should be stressed here that I do not refer to the discussion on whether the welfare state is in general rather a good idea (Barr 2001), or rather an idea leading to problems (Bodor \& Rutkowski 2012). In this paper I focus on the various consequences of the situation, when resources needed for financing welfare state institutions are growing (in terms of GDP) due to population changes, irrespective of whether the institutions are good or bad.

In this paper I analyse selected political economy issues related to pension reforms, such as the worker-retiree conflict of interest, distribution by age of the costs of the loss of demographic dividend, and key goals behind pension reforms. The focus of this paper is on the pension reform in Poland, which actually was an implementation of a thoroughly new pension system. Its design is analysed and discussed from a political economy viewpoint. Furthermore, analysis of the Polish pension system is presented in a broader European context.

\section{The young, the old and the not-yet-old}

Economic literature on pensions is vast. I do not refer to any particular part of this. Rather, I refer to those basic features of pension systems that are crucial for the political economy oriented analysis presented in this paper.

From the macro perspective the pension system is a way to divide the current GDP between the working generation that has produced it, and the retired generation that has not contributed to that but receives a part of the GDP as a pension transfer (given other transfers). That can be illustrated as in Figure 1.

Population ageing has led to a substantial increase in the share of GDP spent on pension transfers $T_{2}>T_{1}$ which implies $R_{2}<R_{1}$. This means the next generation of workers (2) is, in terms of GDP, more poorly remunerated for their activity and productivity growth than the previous generation (1). The figure above focuses exactly on the conflict of interest between the generations.

Figure 1 also illustrates another crucial feature of population ageing: Productivity growth, being essential for social welfare, does not solve the crucial problem caused by the ageing, namely changing proportions in which GDP is divided between the working and the retired generation ${ }^{5}$. The problem we try to solve is related to the proportions of the division, not to the scale of GDP. The same problem of the shrinking remuneration of production factors applies to the more affluent countries as well as to the less affluent. The pension problem is how to keep stable proportions of GDP spent on remunerations as well as on transfers. If the share of GDP spent on pensions is 


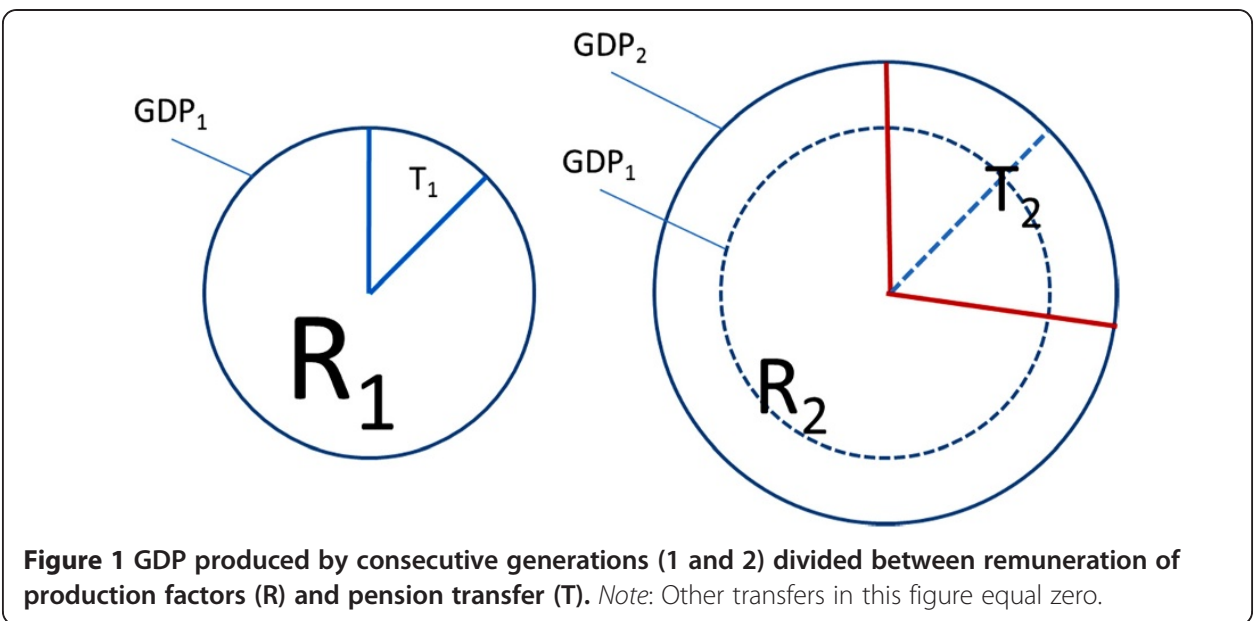

increasing, then the remuneration of labour and capital is decreasing vis-à-vis productivity growth, which seems unsustainable in the perspective of a pension system based on the allocation of income over time. The shrinking (in terms of GDP) remuneration of productivity growth will tend to suppress productivity growth.

The demography driven change in proportions of remuneration of production factors and social (not only pension) transfers indicates a very deep change in the structure of interest within societies. The conflict of interest between labour and capital has been supplemented with another conflict, namely the conflict of interest between the active (financing transfers) and inactive (receiving transfers) citizens. The scale of this latter conflict is growing together with the growing share of GDP spend on financing transfers. However, the conflict of interest has not been fully recognised publicly yet ${ }^{6}$. The pension system is the most directly exposed to the consequences of that situation.

The pension system is an institutional structure for intergenerational exchange between the working generation (workers) and the retired generation (retirees) ${ }^{7}$. The framework can be standardised, based on universal coverage, hence public, or based on individual decisions and responsibility, hence private. In both cases, retirees exchange their pension rights for a part of the production of the workers. These pension rights can be expressed in various ways from well-defined ownership rights to fuzzy political promises. Population structure by age is the crucial factor behind the exchange.

The following simple model illustrates the demographic background of any pension system $^{8}$. The demand side of the market is determined by the number of workers, their productivity and the contribution rate. The number of retirees and their expectations determine the supply side. This can be presented as a simple model, shown in Equations 1a and $1 \mathrm{~b}$.

$$
\begin{aligned}
& D=c \bar{w} e L^{W} \\
& S=z \bar{w} L^{R}
\end{aligned}
$$

where $D$ is the demand for pension rights (a part of GDP spent by the working generation on acquiring pension rights), $S$ is the supply of pension rights (pension expectations of the retired generation in terms of productivity of the working generation), $c$ is the real contribution rate (including subsidies out of general revenues), $z$ is the 
replacement rate ${ }^{9}, w$ (bar) is the average wage, $L^{W}$ is the number of workers, $e$ is the employment rate and $L^{R}$ is the number of retirees.

In equilibrium, the replacement rate is given by Equation (2)

$$
z=c \frac{e}{d}
$$

Where $d$ is the demographic dependency ratio $\left(\mathrm{d}=\mathrm{L}^{\mathrm{R}} / \mathrm{L}^{\mathrm{W}}\right)$.

Given the demographic structure, the employment ratio and the institutional framework (retirement age and so forth), the replacement rate depends on the contribution rate alone and does not depend on the type of pension system or its design. The pension market determines the shares of GDP allocated to each generation.

A key conclusion stemming from the simple model above is that the way pension rights are expressed does not matter for the average level of pensions as measured by the replacement rate ${ }^{10}$. In other words, neither politicians nor financial markets can make a wizardly trick and permanently generate a replacement rate on average larger than $z$, as it is presented in Equation $2^{11}$. This conclusion brings us back to the crucial trade-off within the pension system: whom shall the policy measures protect - workers or retirees? Figure 2 helps to answer that question.

The story behind the figure is as follows. Initially $\mathrm{z}_{1}$ was established based on the consumption needs of the retirees. Then, $\mathrm{c}_{1}$ required to finance pension transfers was imposed. It reflects the entire cost for the working generation. It does not matter here whether the cost is well defined and explicitly paid as a contribution, or the cost is hidden in general revenues spent on subsidisation of the pension system ${ }^{12}$. The goal of the system designers was to keep the rates stable or to fine tune them if needed. That would have been the case if the population structure by age had stayed stable $\left(\mathrm{d}_{1}\right)$. The initial dependency ratio determining the relation of the replacement rate and the contribution rate has been increasing for several past decades and it is expected to keep increasing in the decades to come $\left(d_{2}, d_{3}\right)$. In order to keep the replacement rate at the level promised or even legislated, the contribution rate has to be substantially increased, and/or large open and/or hidden debts have to be made $\left(c_{2}, c_{3}\right)$. Given the demographic projections, it is very likely, actually sure, the replacement rates will sooner or later - be reduced $\left(\mathrm{z}_{4}\right)$.

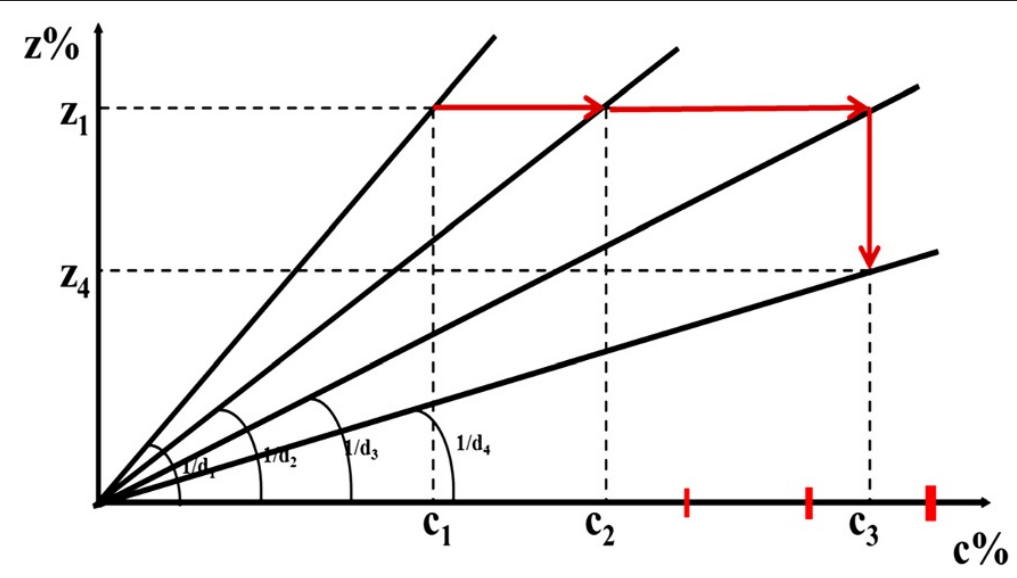

Figure 2 Contribution rate vs. replacement rate. 
The situation as presented above can be modified when, on top of the country's GDP, the pension system is financed out of revenues from investments abroad. That option is available when the system is based on assets traded in financial markets (the socalled funded system). If the rates of return that can be earned abroad are larger than domestic rates, then replacement rates can be larger than " $z$ " as defined in equation (1). This situation can be called "exploitation" or "exchange" of capital for labour. Nevertheless, this option probably also cannot substantially increase " $z$ " in the long run. In any case, international investment can provide pension systems with more risk diversification.

Aiming at an unchanged replacement rate means protecting the retirees at the expense of the workers. That has been the dominant policy option throughout Europe. Remuneration of production factors reflect less and less the supply and productivity growth factors because of the growing cost of pension transfers. Moreover, this situation leads to labour market problems, and in general social problems faced by the youngest generation trying to enter the labour market. They fail to start their adult life enjoying the same level of welfare their parents did. So as the "occupy movement", they express their anger in the streets of European cities. They blame ruthless politicians and bankers for their situation. Those blamed are in many cases guilty of irresponsibility, greed, short-sightedness and stupidity. However, they are not guilty of the loss of "demographic dividend". Reduced resources (no dividend any more) are spent on those who are already in, while those who are still out, namely the young, have little chance to join since the resources are spent.

The difficult situation of the young European generation can be seen via data on unemployment as well as via data on the risk of poverty by age. These are young Europeans who have been hit by the current difficult situation. Table 1 and Table 2 provide data on the risk of poverty by age difference between 2005, the pre-crisis times, and 2010 when the effects of the crisis were revealed. The tables provide data on the largest six EU countries and additionally Greece and Portugal, belonging to the group of countries facing the largest problems in the period analysed on one side, and Sweden being in a relatively good situation on the other. Sweden is also important in this paper because of the pension issues discussed below.

Table 1 At-risk-of-poverty rate by age (percentage change between 2005 and 2010 after transfers (2005 level $=100 \%)$; selected countries)

\begin{tabular}{|c|c|c|c|c|c|c|}
\hline & Total & $65+$ & $50-64$ & $25-49$ & $18-24$ & -18 \\
\hline EU (27 countries) & $100 \%$ & $85 \%$ & $101 \%$ & $104 \%$ & $108 \%$ & $103 \%$ \\
\hline Euro area (17 countries) & $106 \%$ & $80 \%$ & $105 \%$ & $114 \%$ & $119 \%$ & $114 \%$ \\
\hline Germany & $128 \%$ & $105 \%$ & $135 \%$ & $131 \%$ & $127 \%$ & $143 \%$ \\
\hline Spain & $105 \%$ & $74 \%$ & $110 \%$ & $118 \%$ & $140 \%$ & $108 \%$ \\
\hline France & $102 \%$ & $65 \%$ & $83 \%$ & $110 \%$ & $128 \%$ & $124 \%$ \\
\hline Italy & $96 \%$ & $73 \%$ & $90 \%$ & $109 \%$ & $104 \%$ & $105 \%$ \\
\hline Poland & $86 \%$ & $195 \%$ & $101 \%$ & $76 \%$ & $84 \%$ & $77 \%$ \\
\hline United Kingdom & $90 \%$ & $86 \%$ & $92 \%$ & $95 \%$ & $85 \%$ & $89 \%$ \\
\hline Greece & $103 \%$ & $76 \%$ & $95 \%$ & $117 \%$ & $129 \%$ & $113 \%$ \\
\hline Portugal & $92 \%$ & $76 \%$ & $94 \%$ & $97 \%$ & $117 \%$ & $95 \%$ \\
\hline Sweden & $136 \%$ & $153 \%$ & $137 \%$ & $133 \%$ & $116 \%$ & $128 \%$ \\
\hline
\end{tabular}

Source: Eurostat [ilc_li02], own calculations. 
Table 2 At-risk-of-poverty rate by age as compared to the risk for the entire society (selected countries)

\begin{tabular}{lrrrrrr}
\hline & Total & \multicolumn{1}{c}{$\mathbf{6 5 +}$} & $\mathbf{5 0 - 6 4}$ & $\mathbf{2 5 - 4 9}$ & $\mathbf{1 8 - 2 4}$ & $\mathbf{- 1 8}$ \\
\hline EU (27 countries) & 16.4 & $98 \%$ & $82 \%$ & $90 \%$ & $\mathbf{1 2 9 \%}$ & $\mathbf{1 2 5 \%}$ \\
Euro area (17 countries) & 16.1 & $96 \%$ & $84 \%$ & $91 \%$ & $\mathbf{1 3 0 \%}$ & $\mathbf{1 2 4 \%}$ \\
Germany & 15.6 & $90 \%$ & $\mathbf{1 0 9 \%}$ & $90 \%$ & $\mathbf{1 2 1 \%}$ & $\mathbf{1 1 2 \%}$ \\
Spain & 20.7 & $\mathbf{1 0 5 \%}$ & $87 \%$ & $90 \%$ & $\mathbf{1 1 2 \%}$ & $\mathbf{1 2 7 \%}$ \\
France & 13.3 & $80 \%$ & $62 \%$ & $89 \%$ & $\mathbf{1 7 7 \%}$ & $\mathbf{1 3 5 \%}$ \\
Italy & 18.2 & $91 \%$ & $72 \%$ & $97 \%$ & $\mathbf{1 2 6 \%}$ & $\mathbf{1 3 6 \%}$ \\
Poland & 17.6 & $81 \%$ & $93 \%$ & $91 \%$ & $\mathbf{1 1 9 \%}$ & $\mathbf{1 2 8 \%}$ \\
United Kingdom & 17.1 & $\mathbf{1 2 5 \%}$ & $84 \%$ & $80 \%$ & $\mathbf{1 2 2} \%$ & $\mathbf{1 1 9 \%}$ \\
Greece & 20.1 & $\mathbf{1 0 6 \%}$ & $86 \%$ & $90 \%$ & $\mathbf{1 3 7 \%}$ & $\mathbf{1 1 4 \%}$ \\
Portugal & 17.9 & $\mathbf{1 1 7 \%}$ & $90 \%$ & $83 \%$ & $\mathbf{1 0 4 \%}$ & $\mathbf{1 2 5 \%}$ \\
Sweden & 12.9 & $\mathbf{1 2 0} \%$ & $46 \%$ & $82 \%$ & $\mathbf{2 2 9} \%$ & $\mathbf{1 0 2} \%$ \\
\hline
\end{tabular}

Source: Eurostat [ilc_li02], own calculations.

In the tables an increase (Table 1) or a high level (Table 2) of exposure to the risk of poverty is marked in bold, while the opposite is marked in italic. The tables present a gloomy perspective for young Europeans. In the countries presented in both tables, the retirees are protected, while the situation for the young is bad and also worsening. There are two exemptions, namely Poland and Sweden (discussed later in this paper).

Protecting the retirees at the expense of the young is not only a problem for the latter group but also a general social trap. Societies face an asymmetric choice. Protecting the old contributes to the weaker growth of welfare produced by the young, whereas protecting (or at least taking into account) the interests of the young contributes to the stronger growth of welfare for both the old and the young.

Traditional pension systems, as they still dominate in Europe, focus their attention on the old while the interests of the working generation (which is remuneration of their working activity) is residual in those systems. The old are assumed to be weak while the active generation is assumed to be strong. So, the old should be supported by the active generation. That was correct in the past when life expectancy was much lower and people retired around the age of 70 anyway ${ }^{13}$. There is much less rationale when people are living much longer and retire at around the age of 60 . Those who retire are not-yet-old (NYO). Financing their pensions reduces resources available for the remuneration of production factors provided by the working generation, as well as contributing to the growing exposure of the young to the risk of poverty, as presented in Table 1 and Table 2. Redistribution channels should be adjusted to the change. Probably they should be partially reversed. If not, they will be creating social problems rather than mitigating them.

\section{The old pension system in Poland}

A typical traditional continental European pension system existed in Poland until the end of 1998. The system applied a defined benefit (DB) regime. Expenditures on pensions were high by European standards (one of the highest). According to projections, perspectives for the future were gloomy.

The old system was non-transparent. People did not understand its rules and did not care about their own participation in the system (see next sections). The system did 
not know people until the moment they came in and claimed a benefit. Contributions were increasing very rapidly, contributing to growing tax distortions on one hand and growing labour costs and/or declining net remunerations on the other.

However, the key problem of the system was the very low retirement age. Early retirement schemes exist in many countries. Historically they reflect the special preferences given to selected groups, such as railway workers or miners, which were particularly important during the process of industrialisation. Their privileges varied across countries. In Poland, the early retirement scheme for railway workers dated from the early twentieth century. The privilege for miners was based on the crucial role coal mining used to play in the economy of Poland.

The early retirement schemes became a part of the welfare states during the post Second World War prosperity period. People were granted retirement at ages earlier than becoming really old. That dramatically changed the role of pensions. Initially they were to support the very old. As a part of the welfare state they become a "gift" to the notyet-old. The demographic dividend generated enough resources to pay for that. Paradoxically, during the same prosperity period, life expectancy substantially increased. Consequently, the period of time spent on a pension increased from "both ends": workers started retirement earlier and enjoyed it till later ages.

In Poland that process was weaker. Permanent shortages in the labour market prevented pushing workers out of jobs too early. Also life expectancy did not increase to the levels observed in Western European countries. However, just after martial law (1981), a specific factor strongly changed the pension landscape. In order to prevent social unrest in that very politically turbulent period, authorities introduced a massive early retirement scheme for many groups of workers. The official explanation for that was to acknowledge their hard work. In practice, the scheme was available to a large number of workers irrespective of the type of work. Although the legally obliged public system retirement age stayed unchanged, the actual average retirement age started dropping year by year following the ageing of cohorts entitled to the early retirement ${ }^{14}$.

The low retirement age together with the population ageing led to a dramatic increase in pension system expenditure. Up to 1981 the contribution rate was 15.5 per cent of the entire social security. In the mid 1990s the rate was 45 per cent and was insufficient.

\section{A two-fold challenge for Poland: transition towards a market-based econ- omy, and welfare catch-up during the times since the demographic dividend was lost}

Poland started the transition from a centrally planned economy towards a market based economy around $1989^{15}$. The transition was successfully completed by the late $1990 \mathrm{~s}^{16}$. The transition process turned smoothly into the European Union pre-accession process which was also successfully completed in 2004. Since that moment (being still less affluent than most other European countries) Poland has faced universal challenges similar to those faced by the entire EU.

Introducing a market-based economy totally changed economic and social life in Poland. A sharp social and economic upgrade of the country was achieved. However, that success was difficult for people. They had to adjust to a new environment. Introducing 
market-based policies was the task, while the introduction of Western type welfare institutions was an expected reward. It was an attractor, a driving factor behind the transition efforts.

Actually, the pre-transition welfare institutions in Poland, as well as in other countries of the former Soviet bloc, were less developed yet similar to those in the West. Only the overall low productivity did not allow for any generous outcomes from their existence. Nevertheless, people expected not only an increase in welfare but also an easy way to achieve that after joining the West, whose welfare regime was typically perceived as the kind of policy that provided welfare without work - as if welfare was granted to Western European citizens just because they were EU citizens. Actually, that perception is, to an extent, also common in the Western part of continental Europe ${ }^{17}$.

At the end of the 20st century the demographic/financial pyramid went bankrupt throughout Europe. The dividend fuelling the European Social Model was lost. Even very affluent countries became less affluent than their citizens tended to assume. On top of that, former transition countries lost their previously clear and commonly accepted direction of development. After completing one transition (in a narrow sense) they had to pass a second. The transition from a demographic dividend based welfare state to a work effort based regime will be coped with alongside the rest of the EU. However, in this latter case, there is no clear prescription for a successful economic and social policy.

Pension reforms are on the top of policy agendas throughout Europe. Countries have either implemented reforms, are in the course of reforms, or are at least planning reforms of their public pension systems. Poland is in the group that have already implemented a radical pension reform. This reform was based on the document "Security through Diversity" and was implemented in 1999. Figure 3 indicates selected crucial moments of the reform.

The two challenges, namely the transition and the pension reform (together with other structural reforms not discussed in this paper), were not directly connected. Rather, they were two different paths. However, the time coincidence created a unique opportunity to

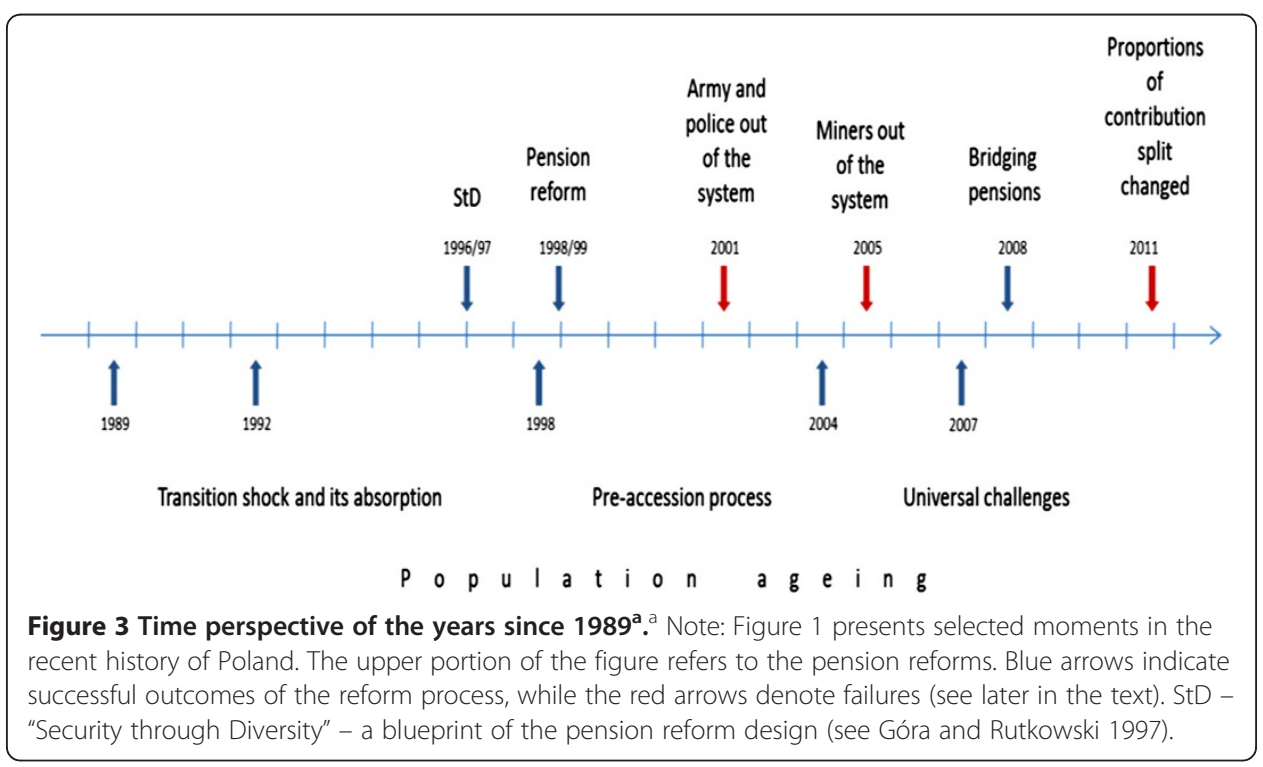


have the radical reform accepted by the people. The transition was commonly treated as a process that was inevitable. The pension reform was not part of the transition, however it was perceived as such. Moreover, the transition meant deep changes across the entire institutional structure of the country. People become accustomed to the changes constantly implemented. Contrary to Western European countries, the stability of institutions was not expected. In consequence, a radical non-intuitive reform had a better chance of being implemented in Poland.

\section{Designing the Polish pension system}

Pension reform is a task involving a number of actors. A key problem behind this is that they commonly strongly discount today versus tomorrow. That stems from human nature as well as from limited knowledge of pension systems. The latter was not so much needed in the past, while it has become necessary recently, now that pension systems do not work properly anymore and require reforms. Designing and implementing reforms - unless implemented in times of strong austerity forced by the current situation - is a forward looking goal.

The design of the pension reform was prepared during times when reform efforts in many countries were dominated by the World Bank blueprint in its early version ${ }^{18}$. It had a lot of influence on the way of thinking in Poland among the general public, politicians and also trade unions ${ }^{19}$. Political processes behind the reform were analysed in literature ${ }^{20}$. Irrespective of many - also disputable - issues, literature highlighted the role of two factors. First was public support for the reform understood as a way to escape "from ZUS" via privatisation of social security ${ }^{21}$. The second factor was the key role played by a group of politically and also institutionally independent designers of the new pension system, and the Office of the Government Plenipotentiary for Social Security Reform led by them.

Successful reform required a number of preconditions, both political and merit based. The political precondition was a more or less widespread feeling that the old pension system was very bad, wasteful, and unfriendly to the people. Moreover, politicians were afraid of the growing expenditure on pensions. The worldwide trend to reform pension systems and the promotion of the reforms by the World Bank created a reform friendly public sentiment.

The radical reform introduced in Poland has had unique political support from consecutive left and right oriented governments since 1996. None of the other structural reforms implemented in the last twenty years have had that type of stable support from changing governments. This situation is also unique compared to other countries. However, because of factors related to internal political dynamics as well as to the general perception of pension reforms in Europe, that unique situation could not have occurred in any other period than in the second half of the 1990s.

The unique broad public support for the reform in its proposed design is seen clearly in the results of an opinion poll carried out in April 1997, before the design of the new pension system had been publicly announced. See Table 3.

I do not pretend to judge to what extent those who supported the pension reform in the late 1990s as well as those who argued against it understood its essence and consequences. Probably at this stage, that could not be objectively measured. However the scale of 
Table 3 Selected elements of the CBOS opinion poll results

\begin{tabular}{|c|c|}
\hline & $\begin{array}{l}\text { YES } \\
\text { answers }\end{array}$ \\
\hline $\begin{array}{l}\text { Pensions should be closely related to the level of contributions and the length of time they were } \\
\text { made }\end{array}$ & 73 per cent \\
\hline $\begin{array}{l}\text { Pensions should be derived from employee contributions, accumulated and capitalised over their } \\
\text { working life }\end{array}$ & 63 per cent \\
\hline The present system does not give a sense of security ${ }^{a}$ & 78 per cent \\
\hline Principles used in the present system are unclear $^{\mathrm{a}}$ & 69 per cent \\
\hline Pensions are subject to political manipulation ${ }^{a}$ & 62 per cent \\
\hline
\end{tabular}

misunderstanding in discussions is large, even after more than ten years from the implementation of the reform.

Irrespective of the historical question, the misunderstandings still present in discussions on pensions stem from the non-intuitive nature of public pension functioning on one hand, and the unclear language used in public debates along with the unclear terminology used in expert discussions on pensions. The former means extremely long-term (several decades) activities are beyond the individual's imagination. The same applies to systems covering the entire population as there is nobody who can grant pensions using resources from outside, while individuals assume the opposite. Especially so, the notion of "state" is misleading as it suggests there is somebody outside of the system who can support it.

Another communication problem stems from the use of the term "pillar". It is used after being defined in a number of ways. In particular, the definition used by European institutions differs from the one used by the World Bank. So in discussing pension issues, people may use the same term having in mind its different meaning. The meaning of the term "pillar" is empty. Among experts that term can be defined well and rigorously according to the accepted meaning. In public debate the term is "fuzzy", while people using it think they discuss the merits of pensions and feel comfortable ${ }^{22}$.

All of these pieces of misunderstanding contributed to the postponing of pension reforms since the public debate was in many cases inconclusive. In Poland the debate led to a clear and strong public support which let the designers prepare an ambitious project reflecting public preferences ${ }^{23}$.

Goals behind the pension system introduced in Poland in 1999:

- Involving the working generation's interests in the design of the pension system

- Partial neutralisation of an increase in tax distortions generated by population ageing

- Universal coverage (no special arrangements)

- Social inclusion of the Not-Yet-Old

Each of the goals needs a piece of explanation.

The interests of the working generation are neglected in traditional pension systems as they were designed in times when that was commonplace. So the working generation who were strong, supported the retirees who were really old and weak. Today (as discussed above) the situation is not like that. The position of the young especially should be made stronger vis-à-vis the position of the NYO. 
The design of the new Polish system aims at balancing the interests of both the working generation and the retired generation.

Population ageing leads to increased expenditure on pensions and other social benefits. That requires an increase in contributions and/or taxes in order to finance the increasing expenditure. In traditional pension systems, contributions are in fact quasi taxes. They contribute to stronger tax distortions and consequently to weaker growth.

The design of the new Polish system aimed at changing the economic nature of contributions perceived as quasi taxes towards contributions perceived as quasi savings.

Special group privileges, as well as general early retirement schemes for those in formal employment (30 years for women and 35 for men), were widespread in the old pension system in Poland. Each group tried to acquire better pension arrangements at the expense of the rest of the population.

The design of the new Polish system aims at a sharp reduction in early retirement schemes (full termination in the future).

Retirement is often looked upon as good, a gift, or as a chance of escaping from the trade-off between income or leisure. In practice, retiring too early is dangerous for the NYO. They are exposed to various risks related to social exclusion.

The design of the new Polish system aims at keeping the NYO employed, not only in order to increase their future benefits, but also in order to reduce their exposure to the risk of social exclusion.

Increasing pensions is not among the goals of the reform, since the struggle for reforms - not only in Poland - is driven by the growing expenditure on pensions. This is logical and clear if one understands the intergenerational nature of pension systems. However, the reform in Poland was welcomed by the public because the people commonly expected higher pensions in the future. Now it is more or less clear to the people that future pensions will be lower (in terms of the replacement rate), but fortunately there is likely no way back, since now it is clear that higher pensions would require higher contributions or taxes. The same strong discounting of today vis-à-vis tomorrow that typically slows down reforms also hampers any potential counter-reform action.

Perception matters for human behaviour. Reforming pensions was necessary to help workers understand that they participated in the pension system, not - as commonly perceived under the rule of the old system - from the moment of retirement, but from the moment of first registered employment. In the old system the employers were obliged to pay contributions for their employees. However, the legal obligation to pay is not equivalent with the economic notion of financing contributions. That concept is clear for economists, but not for the general public, so workers commonly ignored the cost of contributions - they thought that they did not pay.

All incomes (mostly employee wages and salaries) from which contributions needed to be paid had been grossed-up before the reform was implemented. Then the employees began to be obliged to pay 50 per cent of the cost of contributions. There was no net effect for both employees and the employers. The grossing-up did not have any income distribution effect, yet it had an effect on the public perception of participation in the pension system ${ }^{24}$.

Pension issues are dominated by the old-age (OA) portion of social security. This is natural since the expenditure on other types of pensions (mostly disability) are typically small in comparison to expenditure on OA pensions ${ }^{25}$. This situation is different in 
Poland. Not-old-age (NOA) pensions are still much lower than OA pensions, yet are still large when compared to OA pensions that are rather large in absolute terms.

The NOA part of the Polish pension system was not subject to the pension reform introduced in 1999. The NOA pensions, especially disability, are different from the OA pensions. In the past the difference was not so important, while today it is absolutely crucial. The intellectual background for pension systems was created in times when very few workers retired, as the majority of them died before retirement ${ }^{26}$. Consequently, retirement was based on the so-called old-age risk. Based on probability, it was closer to zero than to one. An insurance type way of thinking was suitable in that situation - exactly the same as in the case of disability. Today the probability of retirement (given today's longevity, calling it old-age risk is improper) is close to one. In such a situation, the insurance way of thinking holds true much less in the case of the OA pensions, while it still holds in the case of the NOA pensions. The two parts of social security became different. Their problems should then be dealt with separately. They require different ways of thinking and developing different methods to serve OA and NOA pensions. Disability pensions, and NOA in general have been strongly rationalised in Poland in parallel to the OA pension reform. The rationalisation brought quite strong effects and substantially reduced the number of new disability pensions. I do not however analyse that rationalisation in this paper. Unless directly stated, when referring to pensions, I mean OA pensions.

The new system was presented to the public under the name "Security through Diversity". That was to highlight one of the key ideas behind the system, namely the diversification of risks thanks to a multiplication of methods of income allocation. Instead of one method based on GDP growth, two methods were applied: GDP growth and another employing financial markets. In the end financial markets will generate similar outcomes to a system based just on GDP growth ${ }^{27}$. However, fluctuations in financial markets and fluctuations of GDP are only partially correlated, so a sum of elements using both should be more stable than any of the elements of the sum alone. So the goal was clear - stabilise the pension system.

Channelling pension contributions through financial markets may also - under strong assumptions - contribute to stronger economic growth ${ }^{28}$. This effect matters especially for catching-up economies such as in Poland. Although the pension reform aimed at the goals specified earlier in this paper, a positive externality such as contributing to stronger economic growth was an additional argument for channelling part of the pension contributions through financial markets ${ }^{29}$.

The most crucial element of the new OA pension system was introducing individual accounts. It should be noted that not only the part of the system using the financial markets but the entire system is now based on individual accounts. Moreover, there is nothing carried over from the design of the previous system. The latter was terminated. So in fact the reform of the system in Poland was not actually a reform - it was an exchange of the OA part of the previous pension system for a new OA system.

In the new system two types of individual accounts are used, namely NDC and FDC $^{30}$ :

NDC, non-financial defined contribution system accounts - individual accounts based on non-tradable government quasi-bonds.

FDC, financial defined contribution system accounts - individual accounts based on instruments traded in financial markets 
From an individual's perspective, the new system is a method of life cycle income allocation.

- Contributions based on a fixed percent of individual earnings create account values.

- Account balances from the close of the preceding period earn a rate of return based on the growth of the sum of paid contributions.

- Accumulated account values are annuitised at the time of retirement.

- Annuities are calculated on the basis of accumulated capital and life expectancy at the age of retirement.

In general, people appreciated these rules because they didn't like the previous nontransparent system. The FDC accounts are much better understood (since they are similar to bank accounts). Understanding of the NDC part is less easy. Consequently, many people confuse it with the previous system.

From the pension system participant's side, both types of account work almost identically. The rates of return they generate may temporarily differ but in the long run in the public system they will converge, unless the share of GDP spent on items other than pensions shrinks.

The two types of account differ from the viewpoint of managing flows of contributions. NDC accounts are managed by the Social Security Institute (ZUS) that is also responsible for paying out NDC annuities ${ }^{31}$. The managing of FDC was contracted out to specialised private financial institutions called universal pension societies (PTE). In both cases, flows of contributions stay within the public system. Up until 2012, institutions managing annuities based on FDC accounts had not been established ${ }^{32}$.

The reform was really radical. It looks strange that its implementation was politically easier than the minor reforms being implemented across Europe. However, this was not so strange. Minor reforms are commonly perceived as an attempt to cheat people, while radical reforms may be designed in a way that is an offer for the people. The radical reform implemented in Poland offered, amongst others, transparency in the system.

Exchanging the traditional system for a new OA system based on individual accounts was not just exchanging the defined benefit (DB) regime for defined contribution (DC). That applied only to the accumulation period when participants were active and paid contributions. However, as individual longevity is still random, using just a DC regime may lead to problems reducing the social and economic efficiency of the system.

Individuals do not know how long they will live after retiring. They may guess, however the probability of predicting correctly in an individual case is close to zero. People will underestimate or overestimate the number of years left in retirement. In either case that leads to losing efficiency. In the former case, they will have no means to live from, while still being alive. That would be a problem for them, as well as for the rest of the people who would probably have to cover the cost of consumption of such pensioners for their remaining life span. Overestimation is also bad, since that would mean retirees may have paid lower contributions in the past when they were still workers. That latter problem is particularly important in systems in which retirees may leave bequests. The remaining account value becomes a bequest, which is not a goal for a public pension system as it must then mandate people to participate. Leaving bequests is natural in private systems. 
In a public system the best arrangement for the latter part of life is annuitisation of the account values. There is no efficiency loss due to the unpredictability of lengths of individual life. The social goal of the system, namely an income spread over the entire life span, is also reached. Actually reaching that goal justifies any obligatory participation in the system. If people were to remain without income until the end of their lives, the public pension system would be better to disappear. This is why in the new Polish pension system annuitisation is the only way to pay out OA benefits.

The essence of the design and concept of implementation of the new Polish pension system can be summarized as follows (see Góra (2003)) ${ }^{33}$.

- Focusing on the public (universal) part of the pension system;

- Grossing-up wages in order to let workers participate in the cost of contributions not reducing their net income;

- Separation of the old-age part of social security (OA) from the non-old-age parts of social security (NOA); and segmenting the flows of revenue;

- Termination of the OA part of the previous system;

- Creation of a new OA pension system, based entirely on individual accounts;

- Accrual accounting within the OA system;

- Splitting each person's OA contributions between two accounts (first account - NDC, second account - FDC);

- Annuitisation of account values (NDC as well as FDC) at the same moment of retirement as the pay-out only method;

- Minimum pension supplement on top of both annuities if their sum is below a certain level (financed out of the state budget).

As already mentioned, the key conceptual precondition for the Polish reform was separating the old-age part of the entire social security system from the rest of it. That was crucial since after separating the OA part of the system it was possible to base the entire OA system on individual accounts and nothing else. The new system works along a very clear and transparent rule:

$\mathrm{PV}($ benefit $)=\operatorname{PV}($ contribution $)$

The rule works at the individual level. However, aggregating individual cases leads to the same at the macro level. In short: on the day of retirement a worker gets back the sum of contributions paid plus interest. The latter is generated either by the real economy (in the NDC part) or by financial markets (in the FDC part). The separation of OA and NOA parts means, amongst others, separation of contributions. See Table 4.

The design of the new Polish pension system was based on the available knowledge and experience in the area of pensions in the late 1990s. However, that design did not follow any existing blueprint. That in particular applies to the World Bank promoted version of the "three pillar" pension reform and the Chilean approach. They were important and useful references but were not a pattern to follow. They provided a number of useful technical arrangements. Nevertheless, the final design was different from all patterns, being a design from the new Swedish pension system ${ }^{34}$. The latter and the new Polish system were eventually introduced on the same day, namely $1^{\text {st }}$ January 1999. 
Table 4 Mandatory contributions in Poland before and after implementation of the new pension system

\begin{tabular}{|c|c|c|c|c|}
\hline & Total & $\begin{array}{l}\text { NDC individual } \\
\text { account }\end{array}$ & $\begin{array}{l}\text { FDC individual } \\
\text { account }\end{array}$ & $\begin{array}{l}\text { Other elements of } \\
\text { the system }\end{array}$ \\
\hline \multicolumn{5}{|l|}{ before 1-Jan-1999 } \\
\hline Mandatory contribution & $36.59^{a}$ & - & - & 36.59 \\
\hline \multicolumn{5}{|l|}{ since 1-Jan-1999 } \\
\hline $\begin{array}{l}\text { Mandatory old-age (OA) contribution } \\
\text { [until April 2011] }\end{array}$ & 19.52 & 12.22 & 7.3 & - \\
\hline $\begin{array}{l}\text { Mandatory old-age (OA) contribution } \\
\text { [since May 2011] }\end{array}$ & 19.52 & $17.22^{b}$ & 2.3 & - \\
\hline $\begin{array}{l}\text { Other mandatory social welfare (NOA) } \\
\text { contributions }\end{array}$ & 17.07 & - & - & 17.07 \\
\hline
\end{tabular}

${ }^{a}$ Equivalent of 45 per cent (after grossing-up of labour income).

${ }^{\mathrm{b}}$ In fact since 2011 participants have had two NDC accounts. Contribution (17.22) is split between them: 12.22 and 5.00 percentage points. Later in the text an additional explanation is provided.

The similarity of the new systems introduced in Poland and Sweden is not obvious as in public debate the pension system issues were typically mixed up. There are three levels at which pension systems can be discussed (see Figure 4). The first refers to the most general issues such as social goals and fundamental economic principles. Examples: allocation of income should cover the entire life of each participant; expenditure on pensions cannot grow faster than GDP; a pension system is public if it covers the entire population and applies the same standard rules across all participants, while it is private if it covers individuals or groups whose participation is based on individual decisions and responsibility. The second level refers to the methods applied within the pension system. Methods should reflect the situation and just be efficient. At the third level, regulations should serve the methods and should be logical, clear and transparent.

A good design of pension system should be prepared on all three levels. They are all important. However, they should be subordinated according to the pattern: goals $\rightarrow$ methods $\rightarrow$ regulations. Discussions can lead to a rational conclusion if they follow that

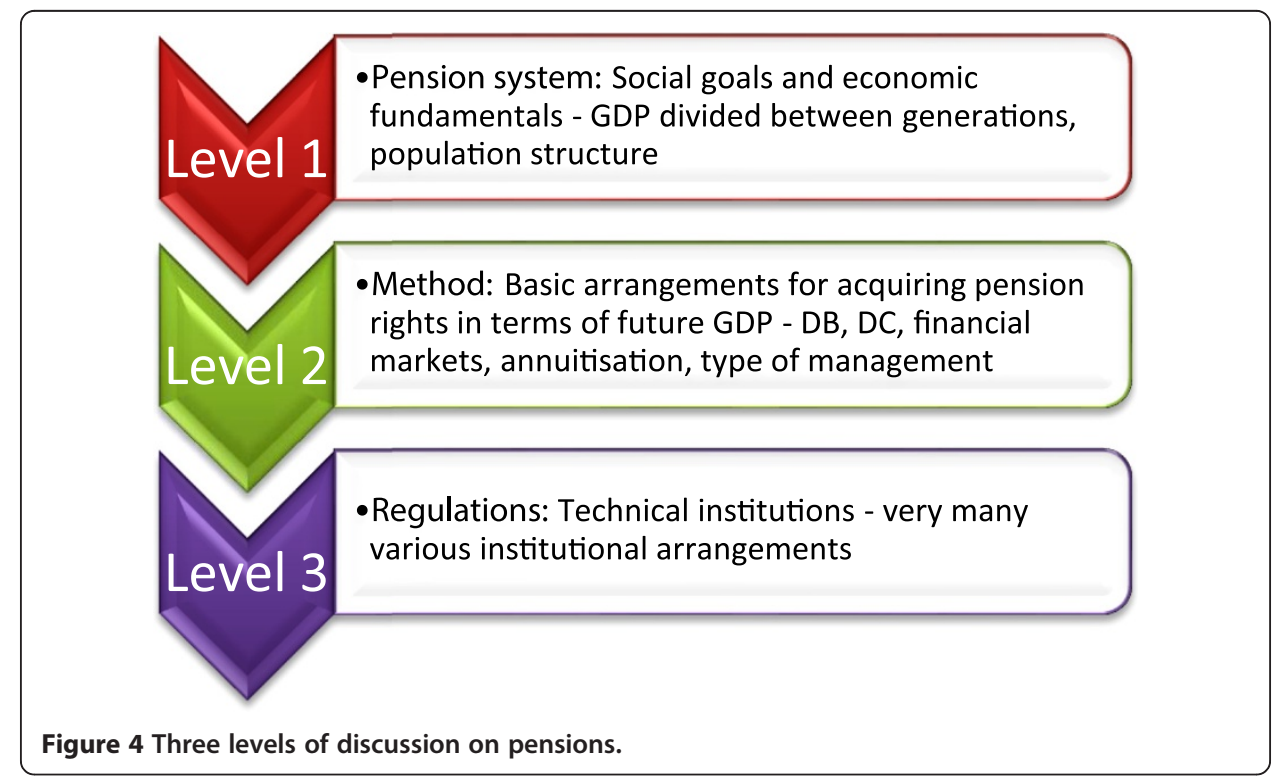


pattern. In public debate the opposite pattern is commonly argued. Rational arguments are discussed with respect to regulations with little reference to the goals behind the public pension system. For instance, is there any sense behind mandating people to participate (pay contributions) if their pensions may not cover their entire life (in the case of a lump-sum payment). Regulations are easier to understand. They are also convenient or inconvenient for the various actors active in the area of pensions, so that regulations are in the centre of public debate as well as expert debate, irrespective of their relation to the merits of the pension system itself.

The Swedish and Polish systems are almost identical at the first level. They are similar at the second. Differences are mostly located at the third level. This is opposite to the similarities between the Polish and the Chilean systems. Similarities can be observed at the third level while the systems differ strongly at the second and especially so at the first level.

In pension literature two approaches are dominant, namely the social policy based and the financial market approaches. Discussion between proponents of the two approaches is probably endless. Neither of the dominant approaches focuses on economics in a way that would permit analysing the long term features and universal coverage of the pension systems together.

The focus on the third level of discussion, which dominates public debate, causes strong misunderstanding of the essence and roots of the Polish pension system. Table 5 highlights key differences between the Security through Diversity and the three pillar approach to pension reform (see also Góra (2003)).

The idea behind the three pillar approach is the partial privatisation of pensions: the second pillar is the same as the third one, it is just mandated. A part of the public system is pushed out to the private sector. The idea behind Security through Diversity is the opposite. It is the diversification of risks within the public system: private asset managers are hired to run a part of the public system using financial markets. The system stays public and is still focused on unchanged social goals. Running a part of the pension system has just been contracted out to the private sector. This arrangement can be called a kind of public-private partnership within the pension system.

Table 5 Alternative approaches to pension reform

\begin{tabular}{|c|c|}
\hline Typical "three pillar" reform & Security through Diversity \\
\hline \multirow{2}{*}{$\begin{array}{l}\text { Downsized and possibly rationalised old system, named } \\
\text { the "first pillar" }\end{array}$} & - Splitting old system into OA and NOA \\
\hline & $\begin{array}{l}\text { Termination of the OA part of the old } \\
\text { system }\end{array}$ \\
\hline \multirow{3}{*}{$\begin{array}{l}\text { New "funded" system named "second pillar" created in } \\
\text { the room left after the downsizing of the old system }\end{array}$} & - Creation of entirely new OA system \\
\hline & - Rationalisation of NOA \\
\hline & $\begin{array}{l}\text { Contribution split between two accounts } \\
\text { within the new OA }\end{array}$ \\
\hline - Contribution split between the old and the new system & $\begin{array}{l}\text { First individual account - non- financial; rate } \\
\text { of return determined by GDP growth }\end{array}$ \\
\hline - Switching process based on individual preferences & $\begin{array}{l}\text { Second individual account - financial; rate of } \\
\text { return determined in financial markets }\end{array}$ \\
\hline - Variety of pay-out methods in the "second pillar" & - Annuitisation of both account values \\
\hline $\begin{array}{l}\text { Promotion of various forms of additional savings, named } \\
\text { the "third pillar" }\end{array}$ & $\begin{array}{l}\text { Promotion of various forms of additional } \\
\text { savings }\end{array}$ \\
\hline
\end{tabular}


The type of approach applied in the Polish pension system is commonly misperceived. In the pension debate both experts and the general public are hostages of the terminology used and assumptions intuitively made. The misperception leads to public communication problems as well as economic problems stemming from the standard accounting methods applied.

\section{Minimum guarantee and the cap on contributions}

The entire new old-age pension system is based on individual accounts. This applies to both the part run by ZUS as well as the one run by PTEs. The way both types of account are managed is different. However, in Poland the role they play in the public system is exactly the same, namely they provide people with a method of income allocation over their life cycle. There is no other role the accounts play; there is no other element of the system other than the accounts. This means that the income redistribution - typically present in public pension systems - has been moved from the pension system to the budget. The sole role for the system is just income allocation. Shifting redistribution out of the OA pension system to the budget follows the demographic changes. On top of that, providing redistribution via the budgetary channel has a number of advantages over doing it via the pension system. See Table 6.

In the OA system itself a minimum benefit guarantee does not exist. On the day of retirement account values are turned into annuities irrespective of the amount accumulated and consequently irrespective of the level of corresponding benefits. However, if a benefit is below a level that is currently legally assumed too low, then a budgetary subsidy comes in to finance a top-up payment increasing the benefit level to the minimum level. This level is left for political discretion. Figure 5 illustrates the idea of the top-up pension benefit. This approach has been implemented in a similar way in both Poland and in Sweden.

The design of the Polish system involves a cap on contributions. System participants pay contributions based on standard rules but only to a level corresponding to 30 times the average wage in the economy. Income above that level is not subject to contribution. This leads to an imposed cap on future benefits. That arrangement looks like a privilege for the rich. This is not the case since the system is not tax-based any more. Contributions to both NDC and FDC accounts are individual savings. The rich can take care of themselves, additionally saving outside the public system.

The cap helps to reduce tax distortions even further than they stem from using individual accounts within the system. The contributions are paid obligatorily. If they are too high then tax perception and consequently tax distortions will always appear. A lack of redistribution causes the additional contributions to not help the less affluent

Table 6 Channelling redistribution via the budget versus via the pension system

\begin{tabular}{lll}
\hline & Via the budget & Via the pension system \\
\hline Redistribution base & Larger & Smaller \\
Who pays (1) & $\begin{array}{l}\text { Generally taxes are usually progressive - so } \\
\text { the rich pay more }\end{array}$ & $\begin{array}{l}\text { Pension contributions are linear - no } \\
\text { progression }\end{array}$ \\
$\begin{array}{l}\text { Who pays (2) } \\
\begin{array}{l}\text { Adjustability to } \\
\text { changing needs }\end{array}\end{array}$ & Labour and capital & Labour \\
\hline
\end{tabular}




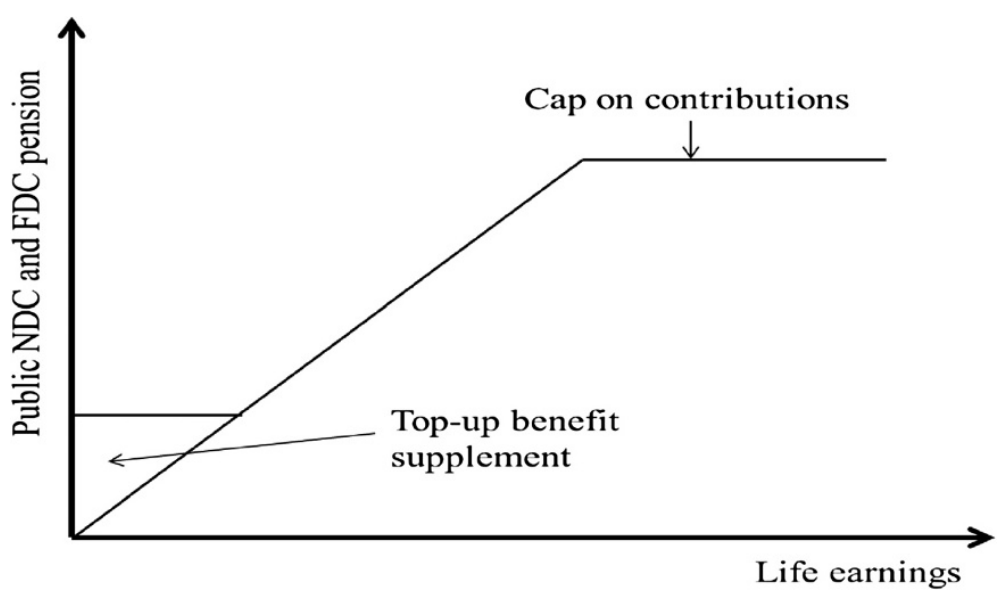

Figure 5 Minimum guarantee and the cap on contributions.

participants. While not paying additional contributions, the rich have to pay taxes on the additional income they earn.

\section{Implementation of the new $O A$ system}

The new system replaced the old one for people born after 31 December 1948. That means that many people were strongly advanced in their working careers. Dropping the old system did not mean a loss of previously acquired pension rights. They were recalculated into account values corresponding to the discounted value of their future pensions to be paid beginning from the retirement age of 60 and 65 for women and men respectively. Thanks to that, the closure of the old system was definitive.

Calculation of the initial capital was relatively easy. This was done by ZUS. However, there were a lot of problems stemming from the inefficiency of the old system. In traditional systems people participated anonymously. The system started recognizing them from the moment they applied for a pension. Each cohort of workers progressed through that procedure before 1999. However, these were people who were approaching retirement age so they were prepared. Knowing the rules of the old system, they had all documents ready. The pension reform had suddenly exposed millions of young people to a situation they were not prepared for. They had to collect a number of documents they had not expected to be necessary ${ }^{35}$. The new system will never need any additional documents in the future. So collecting them was not an additional administrative burden, but just shifting of the burden in a lifetime.

Reform of the pension system in Poland was introduced on 1st Jan. 1999. The old system ceased to exist for people born after $31^{\text {st }}$ Dec. 1948 . They were covered by the new system automatically. Older people did not have any option to switch to the new system. Actually, there was no switching at all, neither for the young nor for the old. See Table 7.

The employed were only to make a decision whether to split their OA contribution before the end of September 1999. No decision was legally interpreted as the decision to leave the contribution non-split and consequently to have the entire contribution managed by ZUS. 
Table 7 Introduction of the new system (age groups)

\begin{tabular}{|c|c|c|}
\hline \multicolumn{2}{|c|}{ New system (people born after 31 Dec. 1948) } & \multirow{2}{*}{$\begin{array}{l}\text { Old system (people born } \\
\text { before } 1 \text { Jan. 1949) }\end{array}$} \\
\hline People born after 31 Dec. 1968 & People born before 1 Jan. 1969 & \\
\hline $\begin{array}{l}\text { Automatically covered by the new } \\
\text { system; OA contribution automatically } \\
\text { split between two accounts [NDC } \\
\text { +FDC] }\end{array}$ & $\begin{array}{l}\text { Automatically covered by the new } \\
\text { system; OA contribution either split } \\
\text { between two accounts or paid into one } \\
\text { account [(NDC+FDC) or NDC] }\end{array}$ & $\begin{array}{l}\text { Stay in the old system (no } \\
\text { possibility to participate in } \\
\text { the new one); no accounts }\end{array}$ \\
\hline
\end{tabular}

The choice of that particular implementation scheme by age was crucial for the following reasons:

- Avoiding general protests typically raised by retirees and people close to retirement;

- Avoiding specific protests against increasing the retirement age;

- Avoiding attempts to make arbitrage by those who could make a choice to switch or not;

- A kind of choice was introduced within the new system to give people more comfort.

It should be noted that the decision to split or not split the OA contribution did not have a strong impact on future pensions. As discussed earlier in this paper, in the public pension system the replacement rate weakly - if at all - depended on the way (type of pension system) in which contributions were managed. The gain following the split of contribution was in risk diversification.

The distribution of the decisions suggests the choices of ages as presented in Table 7 corresponded well to individual preferences. The vast majority of those who in 1999 were only slightly over 30 had decided to split their contributions while the vast majority of those who were about to reach 50 had decided to have their contribution unchanged. That distribution also suggests that the people had made quite rational decisions. Figure 6 illustrates the distribution by age of those decisions.

Decisions on the split of contributions within the new OA system were interpreted by people, as well as the media and politicians, as decisions "to join the new system". That was a complete misunderstanding as the decision referred to two variants of the new system. Leaving the contribution non-split also meant coverage by the new system. There were no particular consequences from this

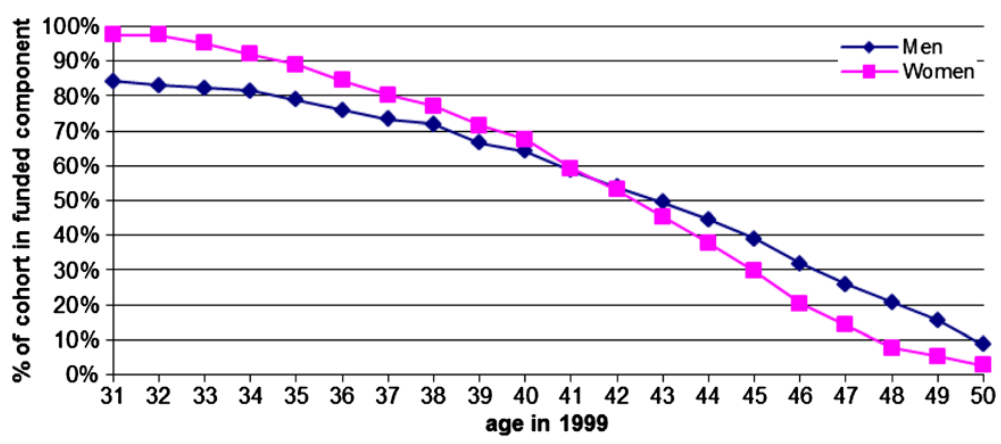

Figure 6 Age distribution of OA contribution split in 1999 for those who had the option to choose. Source: Chlon-Dominczak (2002). 
misunderstanding, it just indicated a strong need for public education to be focused on the area of pensions.

Implementation of the new system meant an increase in the effective retirement age by around 5 years, as the result of changing the former statutory retirement age to become a minimum age. Pension privileges were left outside the new system. According to new legislation there was no way to retire before reaching the new minimum age. Moreover, retiring earlier would mean extremely low pensions, which is the effect of the actuarially neutral way of their calculation.

People in general were in favour of the new system, so they implicitly accepted the retirement age. These were rather young people so they had not started thinking about their own retirement yet. People over the age of 50 were left out of that discussion. The cost of such an approach was in no fiscal saving just after the new system was introduced. Today the saving is large and is increasing year by year, once new regulations on the retirement age have become effective.

\section{Bridging pensions}

The increase in the retirement age - even if not contested in 1999 - was very abrupt. In order to avoid ex-post protests, the concept of bridging pensions was developed. It was part of the entire project of reform implemented in the late 1990s. The termination of early retirement schemes was legislated together with the entire reform bill package. However, the legislation did not include regulations on how the bridging pensions would be organised and financed. That legislation gap was not filled during the 10 years after adoption of the basic law bills. Politicians were afraid of touching that issue again, and this led to problems because the final date by which all early retirement schemes were to be terminated was 2006. Politicians twice postponed that date by one year.

The problem was eventually solved at the end of 2008 when the law on bridging pensions was finally passed through Parliament. Passing the law through Parliament was not easy but finally successful. The law had been vetoed by the President and sent back to Parliament where it was voted on again. Fortunately one opposition party, namely SLD, joined the ruling coalition causing the President's veto to be overruled. The law became effective from the beginning of 2009 and totally changed the pension landscape in Poland.

Key features of the bridging pensions:

- Based on labour medical grounds. There are no other criteria for selecting the entitled work posts. Only occupying such a post for a defined period entitles workers to bridging. No special arrangements exist for any particular group or profession.

- Benefits are provided only for the short period of time between exiting the entitled work post and reaching the minimum retirement age. The period is defined as no more than (typically) 5 years or less.

- Financed (additional contribution) by employers who employ workers in posts that expose their health to risks such as working underground, underwater or those requiring a special health status, such as an aircraft pilot.

- Planned for a finite period. Eventually bridging pensions need to be exchanged for requalification programmes allowing people to work longer in other posts. 
The goals behind the concept:

- Protecting workers health - selling health for the privilege of retiring early should not be possible

- Elimination of hidden subsidisation of those employers who benefit from employing workers in posts exposed to health risks - those who benefit from this employment should cover the cost of the subsequent health risks

- Increasing employment

The introduction of the bridging pensions did not extend the scale of early retirement schemes. Rather the opposite. This was a way to protect the withdrawal of the schemes. The way bridging pensions were defined (labour medical) and their clear cost meant that the number of potential cases was roughly $1 / 10$ th of the previously possible early retirement schemes ${ }^{36}$. Moreover, early retirement was conditional on additional contributions paid earlier by employers. The entire scheme was temporal covering only those workers who had started working in special conditions or in a special capacity before 1999. The law on bridging pensions is commonly referred to as the most important achievement of the government during the term 2007-2011.

\section{Replacement rates and the distribution of income by age}

As already presented, the level of OA pension benefits (as expressed by the replacement rate) did not depend on the particular type of pension system. There was no public pension reform that could increase that level without reducing remuneration of production factors and transfers other than OA benefits. Nevertheless, people still perceived pension systems via the benefits they paid - or actually promised. Consequently, changing a system that generated inflated pension expectations for one that provided true information on future pensions in advance caused social feelings that the change was bad. Even young people from whom the reform released the perspective of the higher contributions and/or taxes felt unhappy. In many cases they even protested.

Pension expectations do matter for social and economic development. If they are inflated, problems will arise sooner or later. From the individual's viewpoint, traditional DB pension systems work ex post, which means pension system liabilities are expressed in monetary terms, after a person retires. In this way, people may and do expect more than a pension system - actually the working people - can and wish to pay. The individual's perception does not take into account equation 2 (earlier in the text). The GDP constraint on expenditure is a macro concept, while at the individual level people still expect what was promised.

The new Polish system works along an ex ante approach: no promises, just well-defined system liabilities as they are now. This contributes to the prevention of such inflated expectations. If the eventual level of pensions is given by the population structure and the contribution rate, then it seems better that people expect what they will eventually receive rather than expecting more. In other words, a reduction of expectations seems better than cutting actual benefits down.

In a DC system, replacement rates additionally depend on the retirement age. The later a person retires, the higher the benefit. Moreover, in actuarially neutral systems, each additional period worked before retirement adds more to the level of the benefit 
than the previous period. Consequently, the issue of replacement rates becomes more complex. The level of the pension is a function of the retirement age. So asking the question 'what will the level of future benefits be' is not precise. One should additionally specify the retirement age corresponding to the question.

Irrespective of the above, future pensions will be smaller than those the previous generations enjoyed. This will just be the effect of the population change. Pensions systems can simply adjust to that change or not. In the latter case demography will be stronger anyway and the adjustment will come anyway - just more dramatically and socially painfully. The ex ante arrangements are better from that viewpoint. They also protect the young much more than the ex post arrangements.

Postponing the inevitable adjustment leads to painful eventual disillusionment. The ex ante approach was implemented well in advance, allowing for a gradual reduction of pension expectations. People covered by the new system (born after 1948) do not have their pension rights simply reduced. Thanks to the initial capital that carries over the rights already acquired, the replacement rates will go down substantially but slowly, which means the actual level of pensions will not substantially change year to year $^{37}$.

It is too early - and in general very difficult - to measure the effect of the implementation of the new pension system on the change of distribution of the risk of poverty by age (as presented in Table 1 and Table 2 ) and to analytically distinguish this effect from the effects stemming from other possible reasons. However, a clear coincidence can be observed in the tables. The shift of that risk from younger to older age groups has been observed for Poland and Sweden - countries that introduced the same type of pension system that involves the interests of the young. The other countries in times of crisis protected the older generation much more strongly than the younger generation. It should be stressed that the retirees' exposure to the risk of poverty is much smaller, even after the sharp change we observed recently.

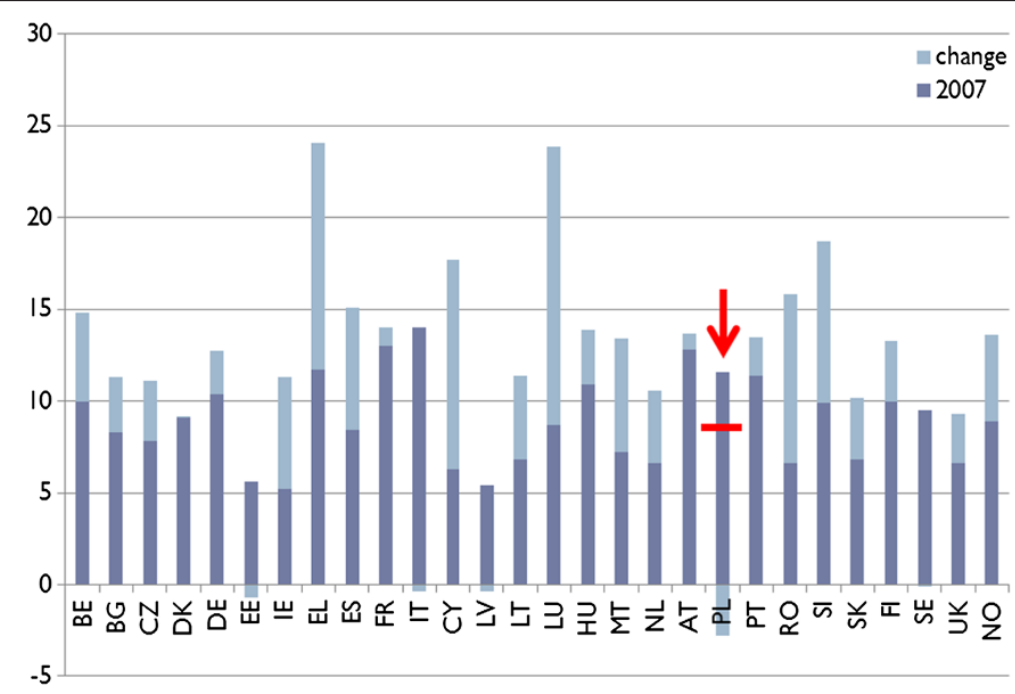

Figure 7 Pension expenditure until 2060. Source: European Commission (2009). 
Protecting the interests of the young can also be derived from projections of future pension expenditure ${ }^{38}$. Figure 7 illustrates the projections. Not going into detail, one can see the projected effect for Poland is different from all other cases ${ }^{39}$. Poland will enjoy a decrease instead of smaller or larger increases in pension expenditure in the decades to come. This do not mean a reduction in pensions - this means remuneration of production factors will be able to grow faster than productivity growth without monetary inflation, which in turn will contribute to stronger long term economic growth.

\section{Missing elements of the new pension system, failures in the reform, and a piece of unexpected progress}

Even though the initial design of the new pension system has almost entirely been introduced, a number of failures can be pointed out. Most of them are the victims of political process; some minor ones are related to the design itself as it was drawn.

\section{Coverage failures - groups still outside the public system}

The public pension system should, by definition, cover the entire population. The system so named 'public' in Poland (as well as in many other countries) has left several special groups outside. So the new system does not cover the entire population. The exceptions are:

- Agricultural workers (actually peasants)

- Judges and prosecutors (exempted from 1999; judges because of the constitution; prosecutors by political action)

- Uniformed services (army, police, firemen and similar; exempted from 2002; by political action)

- Miners (exempted from 2005; street riots just before elections)

Each of the exceptions has a different history and background.

\section{Agriculture - lagging structural adjustment}

The large share of agriculture in total employment is a sign of structural underdevelopment ${ }^{40}$, and has pension system consequences. Before 1972 agricultural workers were not covered by any pension system. Instead of covering them in the public system, a special system was established for this group (KRUS). That system is in fact a mixture of a type of social assistance for the poor living in the countryside, and a method of not paying contributions. More than 90 percent of KRUS expenditure is covered by a budgetary subsidy, so it is a method of redistribution from non-agricultural workers to agricultural workers. The most important problem stemming from that is the motivation for agricultural workers to stay in agriculture instead of flowing to non-agricultural sectors of the economy. Average productivity in agriculture is very low - many times lower than in non-agricultural sectors.

Staying in agriculture is a loss for the agricultural worker since even a low income outside agriculture would be higher than within it. Moreover, the entire economy would benefit from the shift of a large volume of agricultural workers to nonagricultural sectors. Such a shift would not be easy and would depend on their 
adaptability. However, political obstacles prevent the process from starting on a substantial scale ${ }^{41}$.

\section{Strong group pressure}

Judges and prosecutors were strong enough to stay outside the system from the very beginning (1999) and receive generous payments for the entire time after stopping their activity, which they may do relatively early.

\section{Misuse of the pension system}

Uniformed services were initially covered by the new system under standard rules. The only difference was that only the newcomers since 1999 were covered. The rest stayed in their own previous system. That was changed in 2002 for reasons stemming from their commanders' strong willingness to have the "pension" system as a device to implement staff policy.

\section{Miners and street riots}

Miners were also covered by the new system in 1999. The miners went on strike to prevent being covered, but were not successful. That was a great achievement. In 2005 the miners acted again and chose a very delicate moment. Two elections were scheduled for the same year (even the same part of that year), namely the presidential elections and parliamentary elections. Miners' riots in Warsaw frightened politicians enough to eventually accept all their demands. The most important was to withdraw them from the public system. The key argument the miners stressed was the absence of the promised law on bridging pensions.

Politicians will have to cope with these four different challenges. Each will have to be dealt with in a specific way. One good additional outcome of the transparent rules within the public system is that the rest of the population knows and understands more on pensions, so is less keen to accept special arrangements for groups remaining outside of the system.

\section{Design failures}

The NDC part of the system plays a crucial role. Implementation of FDC was more visible and understandable for the people so it played an additional role as an attractor. It was actually the implementation of NDC that was the essence of the reform. The institutional structure behind the NDC part of the system has not yet been developed well enough. There should be a specialised institution running this part of the system. It would also be good if property rights to account values were defined and given to participants. By not having in place these elements of the institutional infrastructure, the NDC part is still underdeveloped and not fully understood by its participants.

An illogical arrangement has been adopted for bequests. They may be left with respect to the FDC part, while they may not with respect to the NDC part of the system. The same arrangement should apply to both of them.

Too lean incentives and regulatory mechanisms to reduce the costs of running the pension system. The newly involved PTEs that run the open pension funds began with 
very high fees in 1999. Later on the fees were substantially reduced yet they remain at a level that is - being lower than in many other systems technically similar to the Polish system - probably still too high. Also, costs within ZUS are too high. They are also not transparent. Actually the public commonly assumes ZUS provides its services for free, while the cost is just covered by tax revenues. Fees charged by PTEs are at least transparent. Costs of ZUS are difficult to calculate. Rough estimations suggest they are not much lower than the costs of the PTEs.

\section{Lacking pieces of law}

There are three key law bills that are still lacking. These are:

- Law on annuities companies - necessary for running the FDC part of the system in the pay-out phase

- Law on coordination of the OA and disability pension systems

- Law on government actuary

The first two were prepared and passed through Parliament but were vetoed by the President in 2008, so did not come into force. The first of them is urgently needed in order to manage paying out benefits ${ }^{42}$. The second is not needed for the proper functioning of the OA system. It is needed in order to prevent creation of pressure on the disability system stemming from the more generous benefits it pays. Both these law bills were vetoed for populist reasons, while the third has just been heavily delayed. It is needed in order to control any politically driven creation of long-term liabilities.

\section{Political manipulation in the pension system's mechanisms}

Initially indexation of NDC accounts was defined as the wage bill growth rate. In the long run it converges to the GDP growth rate. It is like buying shares in a firm. The firm is the entire economy in this case. Having defined the rate of return/indexation, the system is stable by definition. Unfortunately, politicians have changed that definition adding into law that indexation cannot be negative. While sounding good, it introduces potential instability. Pension rights may grow stronger than GDP which means the rights may be inflated. The risk of that situation is probably very limited but still larger than zero.

$\underline{F D C}$ accounts create problems for public finance. According to standard accounting rules, contributions that flow through these accounts and consequently the sum of accumulated account values (system liabilities) are treated as if they were private. However, the real problem is that NDC contributions are treated differently. This motivates politicians to do financial gimmicks. The larger the share of FDC in the contribution split, then the larger the public deficit and debt. Reducing that share automatically improves the situation ${ }^{43}$. However, that is just accounting. In the real economy there is no effect since 1 Zloty (or 1 Euro) generates the same liabilities. Discussing this problem goes beyond the scope of this paper ${ }^{44}$. Here, it is just worth noting that accounting procedures - illogical in fact - have lead to a change in proportions of the split of OA contribution from balanced, namely 12.22:7.3, to one strongly 
overweighting NDC, namely 17.22:2.3. This means the undermining of one of the crucial features of the new OA system which is diversification of risks.

Actually, the change in the split of the contribution was more complicated than only changing the proportions. A third type of individual account was established in the public system. It is very similar to NDC but it offers the possibility of leaving bequests, as in FDC, and it brings a rate of return equal to the nominal GDP growth. The latter is similar to NDC in the long run. The former was introduced in order to avoid legal action against the government.

The change in the proportions of the contribution split weakens diversification of risk within the pension system. However, the change in the proportions did not really change the essence of the system. It stayed entirely DC, which means the political promises did not distort the system. Unfortunately, the way the change was justified was quite devastating to public trust. People partially lost their trust, which is a long term problem ${ }^{45}$.

\section{Unexpected progress}

The pension reform project "Security through Diversity" assumed the same minimum retirement age for men and women at 62. That was not accepted by politicians in 1999 . Actually that was the only initial failure of the reform project at that time. The retirement age stayed at 60/65; women/men. Although at first sight nothing had changed, it was a radical increase in the actual retirement age. In the old system that age was a statutory age, a milestone, while in the new system it became the minimum age. That meant an increase of the actual age by 5 years for both genders. In order to have that radical change implemented in practice, the already discussed law on bridging pensions was necessary.

However, the current government (2012) has gone even further, progressively increasing and equalising the minimum retirement age to 67 for both genders ${ }^{46}$. The effects of that increase will come step by step over the next twenty years. There is however one immediate effect. It is pushing the issue of the bridging pensions out of the political agenda, as well as the previous increase of the actual retirement age that exchanged the statutory 60/65 for the minimum 60/65 retirement age (women/men).

\section{Various additional factors behind the reform}

Pension reform is a difficult challenge. Success is not guaranteed. From the actual experience of many reform attempts, they indicate that failure is rather likely ${ }^{47}$. Recent evidence from many European countries illustrates this very clearly. However, Poland's case has been a success. Below are selected factors that may have helped ${ }^{48}$ :

- The new system was designed by economists who were able to focus on the inputs, outputs and means of the system (rather than by traditional social security experts, who tend to focus mostly on outputs of the system);

- The reform team was decoupled from politics, and was understood to be made up of non-political specialists;

- The new system was designed without pre-set political guidelines; 
- The reform team enjoyed protection from various political powers, under various governments;

- The reform project was presented to the public without strong political affiliation;

- The reform team was not linked to institutions involved in running the old pension system;

- Pre-reform rationalisation of the system was not presented to the public as a reform;

- The new system was presented to the public as a new opportunity (actuarial link of contributions and benefits), not as the axing of the old system promises;

- Strong marketing of the new system (media, social partners);

- The new system was designed and implemented before the real pension crisis started;

- The reform did not affect pensioners and workers already close to retirement;

- The reform did not increase labour cost;

- The old system was terminated but pension rights acquired under its rule were not lost or reduced.

Discussion of the way these factors influenced the reform process is the subject of another paper.

\section{Conclusions}

The design of the new OA pension system in Poland was prepared in a way that fully involved political economy issues. At all three levels of analysis, the public interest dominated technicalities and group interests. Among the most important political economy related issues, the following are the most important:

- Separation of income redistribution and income allocation over the life cycle of an individual.

- Ex ante adjustment of pension expectations instead of ex post adjustments of actual pension benefits.

There is no pension system arrangement that can increase future pensions, as measured by the replacement rate (relative to the wage level of pensions). However, a proper pension system design can prevent inflating pension expectations. The key achievement of the pension reform in Poland was to deliver the bad news to the public that the politicians were not willing to deliver themselves: pensions will be as they will be - dependent on demography in the long run, and on retirement age immediately. That disillusionment is a factor contributing to better remuneration of production factors, which in turn will contribute to the stronger long term growth of the economy.

\section{Endnotes}

${ }^{1}$ Although the challenges are in principle worldwide, in this paper I narrow the focus of my analysis to the European Union and Poland in particular.

${ }^{2}$ For more on the demographic transition see Van de Kaa (1999) or Lee (2003).

${ }^{3}$ See for instance Atkinson (1995), Barr (2001).

${ }^{4}$ See for instance Lindbeck (1995). 
${ }^{5}$ I assume expenditures out of GDP other than remuneration of labour and capital are constant in terms of GDP.

${ }^{6}$ Actually the problem is more complicated since a large number of people are on both sides of the "barricade" financing large transfers, being at the same time transfer recipients. The situation is somewhat natural in developed societies but to an extent only. The problem becomes important after the scale of transfers goes beyond a certain level. Replacing remuneration for economic activity with various transfers (not requiring activity) contributes to larger or smaller reduction in the economic activity. For more see Góra (2012).

${ }^{7}$ For simplicity I use the term "workers" when I refer to the working generation (workers and entrepreneurs) and I use the term "retirees" for older-age recipients.

${ }^{8}$ See Góra (2008).

${ }^{9}$ The replacement rate is relative to the wage measure of pension benefits.

${ }^{10}$ Income redistribution is discussed later in this paper.

${ }^{11}$ Equation 2 presents long term average $\mathrm{z}$ in a closed economy. A so-called funded system can generate larger $\mathrm{z}$ if contributions are invested abroad in markets where rates of return on investment are permanently larger than GDP growth in the country where contribution payers live and plan to receive pensions.

${ }^{12}$ At the micro level the two options can generate different externalities.

${ }^{13}$ See OECD (2011).

${ }^{14}$ According to OECD data the actual retirement age for men fell from above 73 in the late 1960s to 61 around 2000. In the same period the retirement age for women fell from above 72 to around 57. According to Polish internal data the retirement age in the late 1990s was around 60 for men and 55 for women.

${ }^{15}$ Some early reforms liberalising the economy were introduced even earlier, in 1988.

${ }^{16}$ It is difficult to denote a precise date. Probably a good indicator is the year of the Russian crisis, namely 1998.

${ }^{17}$ See Esping-Andersen (1996), Boeri et al. (2000), Esping-Andersen et al. (2002).

${ }^{18}$ World Bank (1994). See also Mueller (2003).

19"Solidarity" trade union openly and strongly supported the Chilean approach promoted by the World Bank.

${ }^{20}$ See Holzmann et al. (2003), Orenstein (2008).

${ }^{21}$ ZUS is a commonly used abbreviation for the name of the Social Security Institute managing the social security system in Poland.

${ }^{22}$ Initially the term "pillar" was used by system designers as there was no alternative (see Góra and Rutkowski (1997), Góra and Rutkowski (1998)). That changed later when more precise arguments were needed (see Góra (2003)).

${ }^{23}$ See Góra and Rutkowski (1998).

${ }^{24} \mathrm{~A}$ side effect of the grossing-up is the need to define contribution rates as a per cent with two decimal digits. That was necessary in order to keep employer and employee net incomes unchanged.

${ }^{25}$ See Eurostat (2012) [spr_exp_pens].

${ }^{26}$ For instance in Germany in the late nineteenth century, life expectancy (at birth, here it is only an indicator) was below 50 while the retirement age was established at 65 (initially even 70) years. Given the longevity today, to copy that initial arrangement, 
countries should increase the retirement age to say 90 - which for many reasons is impossible, of course.

${ }^{27}$ That is the case in a closed economy. If we allow for large international flows of pension savings then financial markets can generate larger or smaller effects.

${ }^{28}$ There is extensive literature on that effect. See for instance Holzmann (1997).

${ }^{29}$ Discussion of that positive effect goes beyond the scope of this paper.

${ }^{30}$ For a broad discussion on NDC and FDC see Góra and Palmer (2004).

${ }^{31} \mathrm{ZUS}$ is a public institution responsible for many tasks. Its role for both managing contributions as well as annuities can also be contracted out to the private sector. This is not an option currently discussed. It is just possible without changing the economic and social essence of the NDC system.

${ }^{32}$ Law on annuities companies was adopted by the Parliament in 2008 but vetoed by the President.

${ }^{33}$ The rationale for the design as presented in Box 1 does not exhaust the issues discussed. I have restricted the presentation to those arguments related to a political economy approach.

${ }^{34}$ For more information on the new Swedish pension system see Palmer (2002).

${ }^{35}$ In the old system only the last 20 years of a working career were taken into account, so people in their $40 \mathrm{~s}$ had just started to collect them.

${ }^{36}$ That cannot be precisely calculated since the number of people previously entitled to early retirement was not known (it was just estimated) and the number of bridging pensions would depend on many factors that were difficult to predict in advance.

${ }^{37}$ The reduction of the replacement will be from around $60 \%$ to around $40 \%$ (for men) and to around $30 \%$ for women. That is of course assuming an unchanged retirement age 60/65. If a 67/67 retirement is assumed the reduction is much smaller. For a broad analysis of this process see Chlon-Dominczak (2002).

${ }^{38}$ See European Commission (2009).

${ }^{39}$ Other countries that will enjoy the improving situation (less sharply than in the Polish case) are those that have implemented radical pension reforms similar to the Polish reform.

${ }^{40}$ Employment in agriculture is between 15 and 20 percent (depending on source; certainly above 15, the EU average is 4.5; Germany 1.6; France 2.1) while the share of agriculture in GDP is around 3 per cent.

${ }^{41}$ The peasant party (PSL) has been and probably will be a part of any ruling coalition in Poland. They firmly protect the current economically and socially inefficient situation.

${ }^{42}$ It is possible the law bill would not have been vetoed if benefits to be paid were indexed according to prices instead of increasing the benefits via profit sharing. The latter would have been better for participants.

${ }^{43}$ The Polish constitution states accumulated debt cannot exceed 60 per cent. There are also early warning limits of debt that trigger measures necessary to stop the increase of the debt. The measures such as freezing indexation of pensions are difficult for the people. 2011 was the Parliamentary election year. Government was under strong pressure not to impose those unpopular measures. So changing the way of accounting of a part of pension flows was strongly and successfully pushed forward.

${ }^{44} \mathrm{~A}$ broad discussion of this issue can be found in Góra (2011). 
${ }^{45}$ Black PR was focused on pension funds but the entire system suffered.

${ }^{46} \mathrm{EU}$ countries are in the process of increasing their statutory retirement ages (Germany 67, Italy 68). However the retirement age of 67 in Poland is the minimum age, which means it is contributing to a very high actual retirement age by European standards.

${ }^{47}$ For a broad analysis of political context of reforms see Bodor and Rutkowski (2012).

${ }^{48}$ As discussed in Góra (2003).

\section{Competing interests}

The IZA Journal of Labor \& Development is committed to the IZA Guiding Principles of Research Integrity. The author declares that he has observed these principles.

\section{Acknowledgements}

The author is grateful to an anonymous referee whose suggestions have greatly improved the paper. Financial support from the Volkswagen Foundation within the project "The Political Economy of Labor Market Reform in Transition Countries: A Comparative Perspective" is also gratefully acknowledged. I thank Sonia Buchholtz for research assistance.

Responsible editor: Hartmut Lehmann

Received: 16 November 2012 Accepted: 5 February 2013

Published: 11 March 2013

\section{References}

Alesina A, Glaeser EL (2004) Fighting Poverty in the U.S. and Europe: A World of Difference. Oxford University Press, Oxford

Atkinson AB (1995) The Welfare State and Economic performance. Natl Tax J 48(2):171-198

Barr N (2001) The Welfare State as Piggy Bank: Information, Risk, Uncertainty and the Role of the State. Oxford University Press, Oxford

Bodor A, Rutkowski M (2012) "NDC Schemes as a Pathway toward Politically Feasible Pension Reform" in Nonfinancial Defined Contribution Pension Schemes in a Changing Pension World. The World Bank, Washington D.C.

Boeri T, Borsch-Supan A, Tabellini G (2000) Would you like to shrink the welfare state? Opinions of European citizens. Econ Pol 32:7-50

Centrum Badania Opinii Społecznej (1997) Opinion Poll Survey. (April)

Chlon-Dominczak A (2002) "The Polish Pension Reform of 1999" in E. Fultz (ed.) Pension Reform in Central and Eastern Europe (Vol. 1: Restructuring with Privatisation: Case Studies of Hungary and Poland). ILO, Budapest

Esping-Andersen G (ed) (1996) Welfare States in Transition. National Adaptations in Global Economies. SAGE Publications Ltd, London

Esping-Andresen G, Gallie D, Hemerijck A, Myles J (2002) Why Do We Need A New Welfare State? Oxford University Press Inc, New York

European Commission (2009) Sustainability report 2009. European Economy 9/2009, Directorate General of Economic and Financial Affairs

Eurostat (2012) Pensions [spr_exp_pens]., http://epp.eurostat.ec.europa.eu

Eurostat (2013) At-risk-of-poverty rate by poverty threshold, age and sex [ilc_li02]., http://epp.eurostat.ec.europa.eu

Góra M, Rutkowski M (1997) "Security through Diversity. Reform of the Pension System in Poland", Office of the Government plenipotentiary for Social Security Reform

Góra M, Rutkowski M (1998) "The Quest for Pension Reform: Poland's Security through Diversity", Social Protection Discussion Paper Series No. 9815. World Bank, Washington D.C.

Góra M (2003) "Reintroducing Intergenerational Equilibrium: Key Concepts behind the New Polish Pension System". Issue 574 of William Davidson Institute working paper series. The William Davidson Institute at the University of Michigan Business School, p 574

Góra M, Palmer E (2004) "Shifting Perspectives in Pensions". IZA Discussion Paper, p 1369, IZA, Bonn

Góra M (2008) "Retirement Decisions, Benefits, and the Neutrality of Pension Systems". ENEPRI Research Report, p 51

Góra M (2011) "Three Pension Issues: A Framework for Rethinking the Basics, Economic Reinterpretation of the Concept of Public Debt, and Pension Systems' Impact on Labour Mobility in the EU". ECFIN, mimeo

Góra M (2012) Preserving social models while regaining competitiveness: can Europe do both? Eur View 11(1):55-62, 2012

Holzmann R (1997) Pension Reform, Financial Market Development, and Economic Growth: Preliminary Evidence from Chile. Staff Papers - Int Monetary Fund 44(2):149-178

Holzmann R, Orenstein M, Rutkowski M (eds) (2003) Pension Reform in Europe: Process and Progress. The World Bank, Washington D.C.

Lee R (2003) The Demographic Transition: Three Centuries of Fundamental Change. J Econ Perspect 17(4):167-190

Lindbeck A (1995) Hazardous Welfare-State Dynamics. Am Econ Rev 85(2):9-15

Mueller K (2003) "The Political Economy of Pension Reform in Central and Eastern Europe", in Reforming Public Pensions. Sharing the Experiences of Transition and OECD Countries. OECD, Paris

OECD (2011) Pensions at a Glance 2011: Retirement-income Systems in OECD and G20 Countries. OECD, Paris 
Orenstein MA (2008) Privatizing Pensions: The Transnational Campaign for Social Security Reform. Princeton University Press, Princeton and Oxford

Palmer E (2002) "Swedish Pension Reform: How Did It Evolve, and What Does It Mean for the Future?". In: Feldstein M, Siebert H (eds) Social Security Pension Reform in Europe. University of Chicago Press, Chicago

Van de Kaa DJ (1999) Europe and its population: the long view. In: van de Kaa DJ, Leridon H, Gesano G, Okólski M (eds) European Populations: Unity in Diversity. Kluwer Academic Publishers, Dordrecht

World Bank (1994) Averting the Old Age Crisis: Policies to Protect the Old and Promote Growth. World Bank, Washington D.C.

doi:10.1186/2193-9020-2-2

Cite this article as: Góra: Political economy of pension reforms: selected general issues and the Polish pension reform case. IZA Journal of Labor \& Development 2013 2:2

Submit your manuscript to a SpringerOpen ${ }^{\circ}$ journal and benefit from:

- Convenient online submission

- Rigorous peer review

- Immediate publication on acceptance

- Open access: articles freely available online

- High visibility within the field

- Retaining the copyright to your article

Submit your next manuscript at $\gg$ springeropen.com 